\title{
Development of a real-time PCR assay for the detection of the golden mussel (Limnoperna fortunei, Mytilidae) in environmental samples
}

\author{
MARCIO R. PIE ${ }^{1}$, PATRÍCIA R. STRÖHER ${ }^{1}$, ANDRÉ O. AGOSTINIS ${ }^{1}$, RICARDO \\ BELMONTE-LOPES ${ }^{1}$, MICHELLE Z. TADRA-SFEIR ${ }^{2}$ and ANTONIO OSTRENSKY ${ }^{3}$ \\ ${ }^{1}$ Departamento de Zoologia, Universidade Federal do Paraná, Av. Cel. Francisco H. dos \\ Santos, 100, Jardim das Américas, 81531-980 Curitiba, PR, Brazil \\ ${ }^{2}$ Departamento de Bioquímica, Universidade Federal do Paraná, Av. Cel. Francisco H. \\ dos Santos, 100, Jardim das Américas, 81531-980 Curitiba, PR, Brazil \\ ${ }^{3}$ Departamento de Zootecnia, Universidade Federal do Paraná, Rua dos \\ Funcionários, 1540, Juvevê, 80035-050 Curitiba, PR, Brazil
}

Manuscript received on October 20, 2016; accepted for publication on November 28, 2016

\begin{abstract}
The golden mussel, Limnoperna fortunei, is among the most devastating invasive species in freshwater habitats worldwide, leading to severe environmental disturbances and economic losses. Therefore, management efforts would be greatly improved by methods that efficiently detect and quantify the abundance of the golden mussel in freshwater habitats, particularly in early stages of colonization. In this study, we describe a highly-sensitive real-time PCR assay targeting a 100-bp region of the COI mitochondrial gene of the golden mussel. The method was able to detect as little as $0.225 \mathrm{pg}$ of target DNA. This assay represents an important contribution to surveillance methods, as well as to optimize field measures to contain and manage populations of the golden mussel in its introduced range.
\end{abstract}

Key words: eDNA, invasive species, environmental DNA, molecular identification.

\section{INTRODUCTION}

The golden mussel Limnoperna fortunei (Mytilidae, Bivalvia) is an invasive bivalve from Southeast Asia rivers (Xu et al. 2015). Due to the characteristics of its reproductive cycle and its high adaptability to different environmental conditions, its great phenotypic plasticity, high fecundity and byssal attachment to different substrates (Iummato et al. 2013), the golden mussel is among the most

Correspondence to: Marcio Roberto Pie

E-mail: marcio.pie@gmail.com important invasive species in continental waters worldwide. Limnoperna fortunei is a very effective ecosystem engineer, altering both ecosystem structure and function, and causes great ecological and economic impacts (Darrigran and Ezcurrade-Drago 2000, Boltovskoy 2015). This species has also invaded hydraulic structures in South America and other Asian countries causing serious biofouling problems (Boltovskoy et al. 2006)

The efficiency of methods for the management and control of the golden mussel depends heavily on the ability of detecting its presence, particularly 
in the early stages of its colonization. To this end, Pie et al. (2006) developed a set of species-specific primers that could be used to detect golden mussel larvae obtained from filtered environmental water. Although the method is clearly an advantage over the laborious and error-prone approach of screening larvae under the microscope, its application is limited by three main factors. First, large volumes of water had to be filtered (typically $>500 \mathrm{~L}$ ), which is a logistic challenge, particularly in remote areas or in turbulent waters. Second, the method only provides binary information in terms of presence or absence of the golden mussel in the obtained samples. Finally, the large fragment that was amplified ( $\sim 300 \mathrm{bp})$ requires that the template DNA is relatively well preserved, allowing for its detection only in the presence of fresh larval tissue in the samples. However, recent studies have sought to detect free DNA molecules in suspension, also known as eDNA, which usually involves smaller fragments (Ficetola et al. 2008, Taberlet et al. 2012). eDNA methods have been particularly useful in monitoring programs of invasive species, including frogs (Ficetola et al. 2008), fish (Darling and Mahon 2011, Keskin 2014) and mudsnails (Goldberg et al. 2013).

In this study we describe a highly-sensitive real-time PCR assay targeting a 100-bp region of the COI mitochondrial gene of the golden mussel. Real-time PCR is a powerful technique that has been used in a variety of applications, including genotyping, gene expression analyses, and pathogen detection (Mackay 2007). In this method, fluorescence data are obtained during the logarithmic phase of the PCR, when the quantity of the amplified product is directly proportional to the amount of initial template, thus circumventing the need for post-PCR processing. Fluorescence is provided by a specific probe, which provides a second layer of specificity in addition to the method (Dias et al. 2008). As a consequence, rtPCR is faster and more accurate than its traditional alternatives
(Wilcox et al. 2013, Nathan et al. 2014). The availability of this new assay could represent an important contribution to improve surveillance methods, as well as to optimize field measures to contain and manage populations of the golden mussel in its introduced range.

\section{MATERIALS AND METHODS}

\section{PRIMER DESIGN}

We downloaded 57 sequences of the cytochrome c oxidase subunit I (COI) mitochondrial gene of the golden mussel available on genbank, particularly those sequenced by Ghabooli et al. (2013) and searched for conserved regions that would allow for the amplification of a short fragment that could be used even in the case of highly degraded environmental DNA. In addition, we targeted a mitochondrial region because there are more mitochondrial DNA copies per cell than nuclear DNA copies, thus maximizing the chance of detection. A set of primers and a probe for a TaqMan ${ }^{\circledR}$ assay were designed using PrimerQuest. To ensure the specificity of the probe, we checked for potential cross amplification using BLAST (Altschul et al. 1990). The probe was synthesized with a 6-GAM reporter dye in the 5'- end and MGB-NFQ as a quencher on the 3'- end.

Sensitivity of the real-time PCR assay was assessed with genomic DNA obtained from adult muscle tissue from Limnoperna fortunei extracted using DNeasy® Blood \& Tissue Kit (Qiagen). Assays were carried out using a StepOnePlus ${ }^{\mathrm{TM}}$ Real-Time PCR System (Applied Biosystems). The test was performed in a series of six 1:10 dilutions from the initial $150 \mathrm{ng} / \mu 1$ of DNA template. Generally the concentrations from eDNA extractions are covered from the spectrum of these dilutions (Spear et al. 2015). To ensure the results, the extractions and PCR were carried out in separate rooms. As commonly used in this kind of experiment to certify the test credibility, a list of controls were 
performed: a standard negative control, a negative control with DNA from a knowing different species and TaqMan ${ }^{\circledR}$ Exogenous Internal Positive Control (Applied Biosystems). Finally, to test for PCR inhibition, we included the amplification of the internal positive control as one of the samples.

Total optimized solution was prepared on a 12.5-uL volume including $6.25 \mathrm{uL}$ of TaqMan ${ }^{\circledR}$ Environmental Master Mix 2.0 (Applied Biosystems), $3 \mu \mathrm{L}$ of DNA as template, $10 \mathrm{nM}$ of each primer, $25 \mathrm{nM}$ of probe, $0.3 \mu \mathrm{L}$ of TaqMan ${ }^{\circledR}$ Exogenous Internal Positive Control 10X Exo IPC Mix (Applied Biosystems), $0.15 \mu \mathrm{L}$ of TaqMan ${ }^{\circledR}$ Exogenous Internal Positive Control 50X Exo IPC DNA (Applied Biosystems) and $2.8 \mu \mathrm{L}$ of Ambion ${ }^{\circledR}$ DEPC-treated water $\left(\right.$ Ambion $\left.{ }^{\circledR}\right)$. All samples ran in triplicate for templates and negative controls. The reaction was performed with $95^{\circ} \mathrm{C}$ for $15 \mathrm{~min}$ followed by 40 cycles of denaturation at $94^{\circ} \mathrm{C}$ for $1 \mathrm{~min}$ and annealing/extension at $65^{\circ} \mathrm{C}$ for $1 \mathrm{~min}$.

Finally, we tested the performance of the method under field conditions by collecting 100 $\mathrm{mL}$ water samples from reservoirs of electric power plants in the state of Paraná for which the golden mussel was recorded as either present (Usina Salto Osório - São Jorge D’oeste, and Usina Governador José Richa - municipality of Capitão Leônidas Marques) or absent (Usina Salto Santiago - municipality of Saudade do Iguaçu, Usina Governador Bento Munhoz da Rocha Netto municipality of Pinhão, and Usina Governador Ney Aminthas Braga - municipality of Mangueirinha). This classification, in turn, was defined either based on previous studies by our own team and through confirmatory analyses based on the collection of environmental samples and screening larvae under the microscope. Each sample was filtered using a $47 \mathrm{~mm}$ diameter and $45 \mu \mathrm{m}$ pore size nitrocellulose membrane. Total DNA was extracted using a DNeasy ${ }^{\circledR}$ Blood \& Tissue (Qiagen) kit, following the manufacturer's instructions, using the whole filter rolled up in the microtube for digestion.

\section{RESULTS}

The designed real-time PCR assay primers and probe are shown in Table I. The in silico analysis using NCBI blast showed that the primers did not match other bivalve species. The assay amplifies a $100 \mathrm{bp}$ region of the COI gene, corresponding to coordinates 316-412 of the matching gene in Crassostrea angulata (AB904890). There was a linear range of detection over five orders of magnitude, with little variation among replicates (Figure 1).

TABLE I

Sequences of primers and probe used in our assay for the detection of the golden mussel.

\begin{tabular}{ll}
\hline Name & Sequence $\left(5^{\prime}-3^{\prime}\right)$ \\
\hline $\begin{array}{l}\text { Forward } \\
\text { primer }\end{array}$ & GGGACTGGTTGGACAGTTTAT \\
Probe & $\begin{array}{l}\text { 6FAM- } \\
\text { CCCAGCAGTTGACATAGCTGCTTT- }\end{array}$ \\
& MGB-NFQ (Sense) \\
$\begin{array}{l}\text { Reverse } \\
\text { primer }\end{array}$ & ACGCACCAGCTAAATGAAGA \\
\hline
\end{tabular}

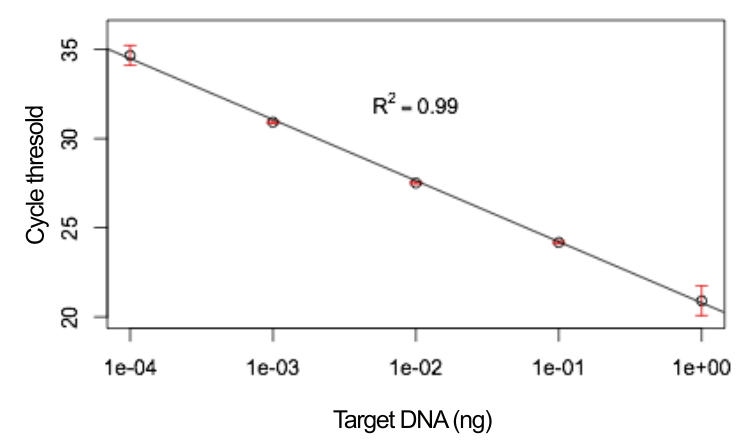

Figure 1 - Sensitivity of the Limnoperna fortunei real-time PCR assay. Dilutions were made from genomic DNA and mean values of cycle threshold $(\mathrm{Ct})$ plotted against $\log _{10}$-transformed DNA concentrations. Error bars represent standard deviations over three replicates. 
Field tests of the protocol described in this study were highly efficient, given that none of the locations where the golden mussel had not been recorded were tested positive, whereas the method indicated the presence of the golden mussel in both of the reservoirs where populations had been detected.

\section{DISCUSSION}

The most crucial moment for the management of invasive species is precisely that in which it is less detectable, i.e. during the early stages of colonization. Therefore, efficient efforts to monitor and control the golden mussel depend heavily on a means for its early detection. In this study we provide a new TaqMan ${ }^{\circledR}$ rtPCR assay that can be used for this purpose. Future tests under field conditions should allow for assessing the extent and operational conditions under which the quantitative information provided by the assay can translate into reliable estimates of golden mussel biomass, as has been proposed for other organisms (e.g., Takahara et al. 2012, Goldberg et al. 2013, Pilliod et al. 2013).

An alternative to the method presented in this study has been designed by Endo et al. (2009), in which a SYBR-Green assay was developed to amplify a $139 \mathrm{bp}$ fragment of the golden mussel COI gene. Given that our primer set would amplify a fragment that is nearly $40 \%$ shorter than that designed by Endo et al. (2009), we expect that our method will be more sensitive and robust to template degradation, as commonly observed in environmental DNA. In addition, the use of the TaqMan ${ }^{\circledR}$ probe provides an additional level of specificity in our assay in relation to an alternative SYBR-Green assay.

\section{ACKNOWLEDGMENTS}

MRP and AO were supported by a research grant from Conselho Nacional de Desenvolvimento
Científico e Tecnológico (CNPq) (304897/20124 and 302609/2013-0, respectively). We thank Companhia Paranaense de Energia Elétrica (COPEL) for partnership to carry out the work and Diego Junqueira Stevanatto and Diogo Barbalho Hungria for assistance during field work.

\section{REFERENCES}

ALTSCHUL SF, GISH W, MILLER W, MYERS EW AND LIPMAN DJ. 1990. Basic local alignment search tool. J Mol Biol 215(3): 403-410.

BOLTOVSKOY D. 2015. Limnoperna fortunei: the ecology, distribution and control of a swiftly spreading invasive fouling mussel. Springer International Publishing 10: 476.

BOLTOVSKOY D, CORREA N, CATALDO D AND SYLVESTER F. 2006. Dispersion and Ecological Impact of the Invasive Freshwater Bivalve Limnoperna fortunei in the Río de la Plata Watershed and Beyond. Biol Invasions 8: 947-963.

DARLING JA AND MAHON AR. 2011. From molecules to management: adopting DNA-based methods for monitoring biological invasions in aquatic environments. Environ Res 111(7): 978-988.

DARRIGRAN G AND EZCURRA-DE-DRAGO I. 2000. Invasion of the exotic freshwater mussel Limnoperna fortunei (Dunker, 1857) (Bivalvia, Mytilidae) in South America. Nautilus 114: 69-73.

DIAS PJ, SOLLELIS L, COOK E, PIERTNEY SB, DAVIES IM AND SNOW M. 2008. Development of a real-time PCR assay for detection of Mytilus species specific alleles: application to a sampling survey in Scotland. J Exp Mar Biol Ecol 367(2): 253-258.

ENDO N, SATO K AND NOGATA Y. 2009. Molecular based method for the detection and quantification of larvae of the golden mussel Limnoperna fortunei using real-time PCR. Plank Benth Res 4(3): 125-128.

FICETOLA GF, MIAUD C, POMPANON F AND TABERLET P. 2008. Species detection using environmental DNA from water samples. Biol Lett-UK 4(4): 423-425.

GHABOOLI S, ZHAN A, SARDIÑA P, PAOLUCCI E, SYLVESTER F, PEREPELIZIN PV, BRISKI E, CRISTESCU ME AND MACISAAC HJ. 2013. Genetic diversity in introduced golden mussel populations corresponds to vector activity. PLoS ONE 8(3): e59328.

GOLDBERG CS, SEPULVEDA A, RAY A, BAUMGARDT J AND WAITS LP. 2013. Environmental DNA as a new method for early detection of New Zealand mudsnails (Potamopyrgus antipodarum). Freshw Sci 32(3): 792-800. IUMMATO MM, DI FIORI E, SABATINI SE, CACCIATORE LC, COCHÓN AC, DE MOLINA MC 
AND JUÁREZ AB. 2013. Evaluation of biochemical markers in the golden mussel Limnoperna fortunei exposed to glyphosate acid in outdoor microcosms. Ecotox Environ Safe 95: 123-129.

KESKIN E. 2014. Detection of invasive freshwater fish species using environmental DNA survey. Biochem Syst Ecol 56: 68-74.

MACKAY IM. 2007. Real-time PCR in microbiology: from diagnosis to characterization. Caister Academic Press, 454 p.

NATHAN LM, SIMMONS M, WEGLEITNER BJ, JERDE CL AND MAHON AR. 2014. Quantifying environmental DNA signals for aquatic invasive species across multiple detection platforms. Envir Science Tech 48(21): 1280012806.

PIE MR, BOEGER WA, PATELLA LA AND FALLEIROS RM. 2006. A fast and accurate molecular method for the detection of larvae of the golden mussel Limnoperna fortunei (Mollusca: Mytilidae) in plankton samples. J Mollus Stud 72: 218-219.

PILLIOD DS, GOLDBERG CS, ARKLE RS AND WAITS LP. 2013. Estimating occupancy and abundance of stream amphibians using environmental DNA from filtered water samples. Canadian J Fish Aquat Sci 70(8): 1123-1130.

SPEAR SF, GROVES JD, WILLIAMS LA AND WAITS LP. 2015. Using environmental DNA methods to improve detectability in a hellbender (Cryptobranchus alleganiensis) monitoring program. Biol Conserv 183: 3845.

TABERLET P, COISSAC E, HAJIBABAEI M AND RIESEBERG LH. 2012. Environmental DNA. Molecular Ecology 21(8): 1789-1793.

TAKAHARA T, MINAMOTO T, YAMANAKA H, DOI H AND KAWABATA ZI. 2012. Estimation of fish biomass using environmental DNA. PloS ONE 7(4): e35868.

WILCOX TM, MCKELVEY KS, YOUNG MK, JANE SF, LOWE WH, WHITELEY AR AND SCHWARTZ MK. 2013. Robust detection of rare species using environmental DNA: the importance of primer specificity. PloS ONE 8(3): e59520.

XU M, WANG Z, ZHAO N AND PAN B. 2015. Growth, reproduction, and attachment of the golden mussel (Limnoperna fortunei) in water diversion projects. Acta Ecol Sin 35: 70-75. 